\section{First Case of Ochroconis humicola Infection in Marine Cultured Fish in Japan}

\author{
Shinpei Wada, Kazuyo Nakamura \\ and Kishio Hatai
}

\begin{abstract}
Division of Fish Diseases, Nippon Veterinary and Animal Science University, Kyohnan-cho 1-7-1, Musashino, Tokyo 180, Japan
\end{abstract}

(Received March 2, 1995)

Key words: Ochroconis humicola, devil stinger, Inimicus japonicus, mycotic disease

Recently, a new disease characterized by open ulcers on the body surface has been found in cultured devil stinger, Inimicus japonicus (Synanceiidae; Japanese name: Oni-Okoze) in the south-west region of Japan. We examined a total of five fish averaging 1.4 $\mathrm{g}$ in body weight collected from Kagoshima Prefecture at the end of January 1994. In this paper, the authors describe the isolated potential fungal pathogen, Ochroconis humicola from the lesions and its histopathology.

In four out of the five fish examined, open ulcers were formed at dorsal part of the body surface (Fig. 1). Although the fish examined showed little appetite, no mortality was recorded. The center of the lesion was necrotic and sloughed, leaving trunk muscles exposed in a crater-shaped cavity surrounded by an erosious periphery. Direct microscopical examination of the exposed trunk muscles revealed numerous fungal hyphae, which were septate and approximately 1 to $2 \mu \mathrm{m}$ in width.

Fungi were isolated by inoculating a small piece of trunk muscle of the fish on glucose-yeast extractpeptone-seawater (PYGS) agar ${ }^{1)}$ at $25^{\circ} \mathrm{C}$. To inhibit bacterial growth, $500 \mu \mathrm{g} / \mathrm{m} l$ each of ampicillin and streptomycin sulfate were added to the medium. Fungal colonies were subcultured on PYGS agar to obtain pure cultures. The isolate NJM 9471 was used for more detailed examination. The identification was made by the slide culture method at $25^{\circ} \mathrm{C}$. Using light microscopy, the slide cultures were examined for conidiogenesis.

Fungal colonies on PYGS agar were slowgrowing; colonies were slightly domed, velvety to floccose and pale brown in color. Hyphae were septate, pale brown in color and 1 to $2 \mu \mathrm{m}$ in width. Conidia were usually sparse, $1.8-2.2 \times 7.0-10.0 \mu \mathrm{m}$,

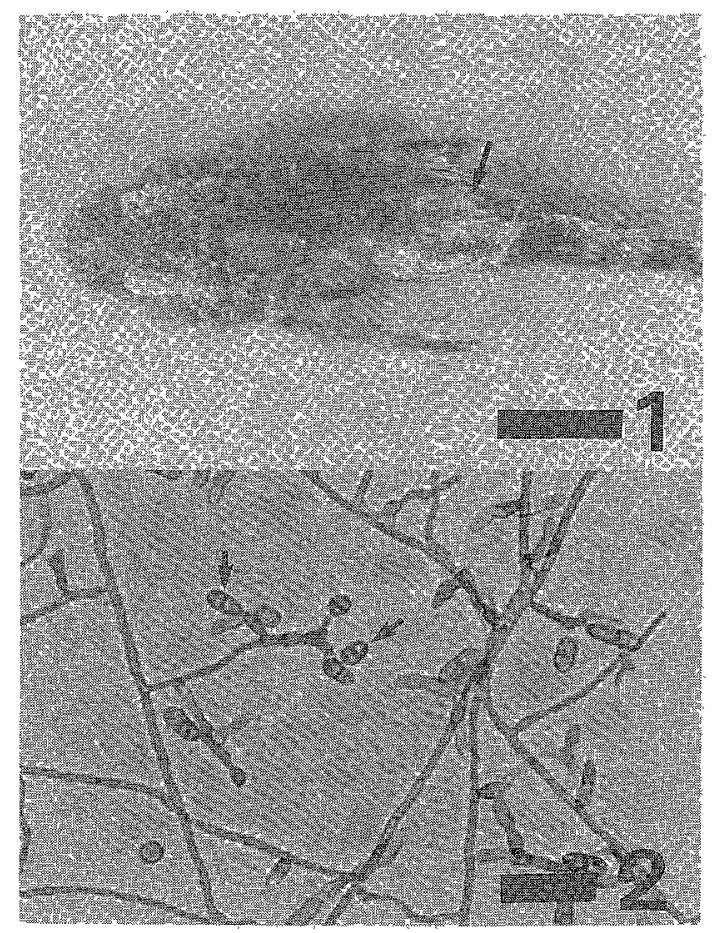

Fig. 1. Dorsal view of the fish examined. Note open ulcer on the dorsal body surface (arrow). Bar $=1 \mathrm{~cm}$.

Fig. 2. Two-celled conidia of the isolate NJM 9471 on PYGS agar (arrows). Bar $=10 \mu \mathrm{m}$.

two-celled, smooth-walled, pale brown in color and cylindrical with rounded ends (Fig. 2). The reproductive mode of the conidia was sympodial. It was identified as Ochroconis humicola according to de Hoog and von $\mathrm{Ar}^{2)}$ and Howard ${ }^{3)}$ from the characteristics mentioned above.

After removal of a portion of ventrolateral abdominal body wall, the fish were routinely necropsied. All organs were fixed in 10\% phosphatebuffered ( $\mathrm{pH}$ 7.0) formalin solution. The fixed tissues were processed to make paraffin sections and stained with $H \& E$, methenamine silver-nitrate, Grocott's variation and counter-stained with Giemsa (Grocott-Giemsa), perodic acid Schiff (PAS) reaction, Schmorl method and Hucker-Conn method.

Histopathologically, tissue from epidermis to stratum compactum extensively sloughed, leaving wide necrotic area in the trunk muscle layer. Zonal bacterial colonies consisting of numerous Gram-negative short rods were found in the superficial layer of the lesions. Large numbers of septate fungal hyphae, 1 


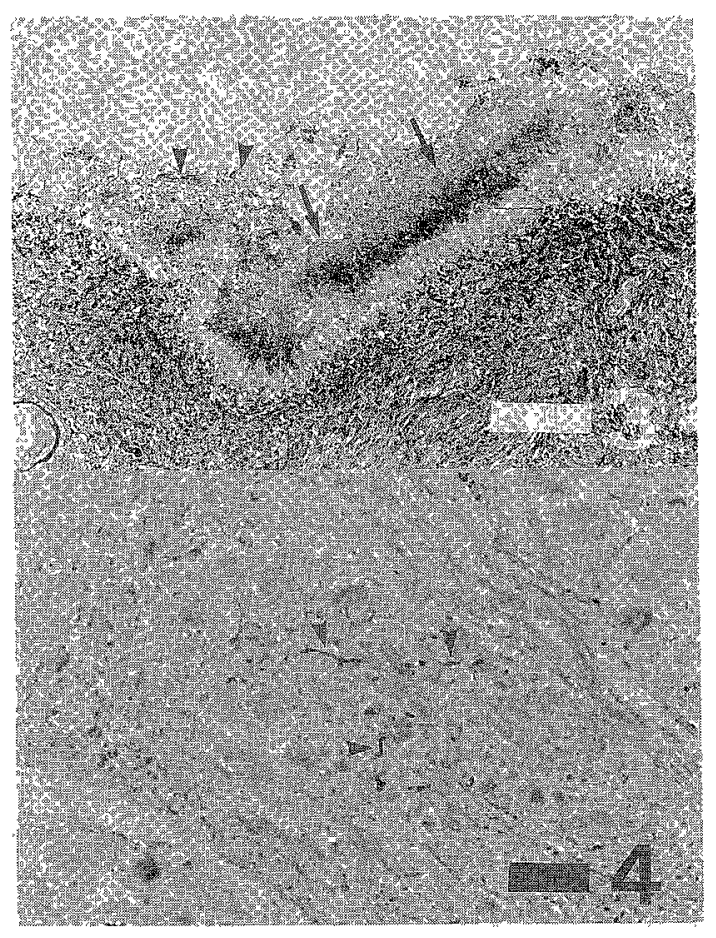

Fig. 3. Transverse section of the ulcerative lesion. Note zonal colonies of bacteria (arrows) with numerous fungal hyphae (arrow heads). GrocottGiemsa. Bar $=100 \mu \mathrm{m}$.

Fig. 4. Fungal hyphae (arrow heads) penetrating into deeper layer of the trunk muscle. GrocottGiemsa. Bar $=20 \mu \mathrm{m}$.

to $2 \mu \mathrm{m}$ in width, were also found in and around the bacterial colonies (Fig. 3). Although the hyphae were stained pale brown with $\mathrm{H} \& \mathrm{E}$ and positively with PAS reaction and Schmorl method, they were more easily recognized in Grocott-Giemsa preparation. These characteristics of the hyphae suggested that they belonged to imperfect fungi with melanin pigment in their hyphae, and therefore, they should be classified as dematiaceous fungi ${ }^{4}$. The morphological characteristics of the fungus was consistent with these of the isolate NJM 9471. Hyphae penetrated into the deeper layer of skeletal muscles (Fig. 4), some surrounded by epithelioid cell granulomata without association of multinuclear giant cells. They did not reach the visceral organs. Bacteria were not observed in the deeper layer of skeletal muscles and visceral organs. Tissue reactions consisted of exten- sive infiltration of eosinophilic granular cells and mono-nuclear cells, morphologically consistent with macrophages, associated with severe hemorrhage.

Fungal disease in fish due to the genus Ochroconis was first reported in the kidneys of chinook salmon, Oncorhynchus tshawytscha under the name Heterosporium tshawytschae ${ }^{5)}$. It was transferred to the genus Scolecobasidium ${ }^{6}$ ) and subsequently named as Ochroconis tshawytschae ${ }^{7)}$. Ochroconis humicola was reported as a fish pathogen in the kidneys of coho salmon, Oncorhynchus kisutsh ${ }^{8)}$, and rainbow trout, Oncorhynchus mykiss ${ }^{9}$, and Ochroconis sp. infection was described in masu salmon, Oncorhynchus masou, in $\mathrm{Japan}^{10,11)}$. However, all the previous reports described visceral mycoses in freshwater fish. In Japan, cases of fungal diseases in cultured marine fishes due to imperfect fungi have been restricted to Fusarium oxysporum infection of red sea bream, Pagrus sp. ${ }^{12)}$ and Scytalidium infestans infection of cultured striped jack, Pseudocaranx dentex ${ }^{13)}$. Therefore, the present Ochroconis humicola infection is not only the first report in cultured marine fish, but also the first record from Japan.

\section{References}

1) Bain, B. Z., K. Hatai, G. L. Po and S. Egusa (1979): Tran. Mycol. Soc. Japan, 20, 115-124. 2) de Hoog, G. S. and J. A. von Arx (1973): Kavaka, 1, 55-60. 3) Howard, D. H. (1983): Fungi pathogenic for human and animals, Part A. Biology. Marcel Dekker, Inc., New York, New York, 652 pp. 4) Hawkinsworth, D. L., B. C. Sutton and G. C. Ainsworth (1983): Ainsworth and Bisby's dictionary of the fungi, 7th ed., Commonwealth Mycological Institute, Kew, Surrey, England, 445 pp. 5) Doty, M. S. and D. W. Slater (1946): Am. Midland Naturalist, 36, 663-665. 6) Mcginnis, M. R. and L. Ajello (1974): Trans. Brit. Mycol. Soc., 63, 202-203. 7) Kirilenko, T. C. and M. A. AllAchmed (1977): Mikrobiologichnii Zhurnal, 39, 303-306. 8) Ross, A. J. and W. T. Yasutake (1973): J. Fish. Res. Board Can., 30, 994-995. 9) Ajello, L., M. R. McGinnis and J. Camper (1977): Mycopathologia, 62, 15-22. 10) Kuroda, N., K. Hatai, S. S. Kubota and M. Isoda (1986): Bull. Nippon Vet. Zootech. Coll., 35, 151-157. 11) Hatai, K. and S. S. Kubota (1989): J. Wildlife Dis., 25, 83-88. 12) Hatai, K., S. S. Kubota, N. Kida and S.-I. Udagawa (1986): J. Wildlife Dis., 22, 570-571. 13) Iwatsu, T., S.-I. Udagawa and K. Hatai (1990): Trans. Mycol. Soc. Japan, 31, 389-397. 